University of Nebraska - Lincoln

DigitalCommons@University of Nebraska - Lincoln

1988

\title{
HYDRAULIC FRACTURING IN SITU STRESS MEASUREMENTS TO 2.1 KM DEPTH AT CAJON PASS, CALIFORNIA
}

John H. Healy

U.S. Geologic Survey

Mark D. Zoback

Stanford University, zoback@stanford.edu

Follow this and additional works at: https://digitalcommons.unl.edu/usgsstaffpub

Part of the Earth Sciences Commons

Healy, John H. and Zoback, Mark D., "HYDRAULIC FRACTURING IN SITU STRESS MEASUREMENTS TO 2.1 KM DEPTH AT CAJON PASS, CALIFORNIA" (1988). USGS Staff -- Published Research. 448.

https://digitalcommons.unl.edu/usgsstaffpub/448

This Article is brought to you for free and open access by the US Geological Survey at DigitalCommons@University of Nebraska - Lincoln. It has been accepted for inclusion in USGS Staff -- Published Research by an authorized administrator of DigitalCommons@University of Nebraska - Lincoln. 


\title{
HYDRAULIC FRACTURJNG IN SITU STRESS MEASUREMENTS TO 2.1 KM DEPTH AT CAJON PASS, CALIFORNLA
}

\author{
John H. Healy \\ U.S. Geological Survey, Menlo Park, CA \\ Mark D. Zoback \\ Department of Geophysics, Stanford University, CA
}

\begin{abstract}
Stress measurements to $2.1 \mathrm{~km}$ reveal stress changes with depth that cannot be explained by an elastic response to uniform crustal strain. The data at about $1 \mathrm{~km}$ depth suggest that the stress is limited by the frictional strength of rock and is perturbed at greater depths by faults which intersect the borehole. The stress data indicate that there is little or no right-lateral shear stress acting on planes parallel to the San Andreas Fault.
\end{abstract}

\section{Introduction}

In this paper we present the results of stress measurements at Cajon Pass, California to a depth of $2.1 \mathrm{~km}$. The measurements were made in two holes 50 meters apart. In 1985 we used a small USGS drilling rig to make measurements of stress and temperature in an exploratory well drilled by the ARKOMA Production Company. Drilling of DOSECC hole at Cajon Pass was begun in 1986. We describe here in in situ stress measurements made in the ARKOMA hole at depths between 0.9 to $1.3 \mathrm{~km}$ and in the DOSECC hole at depths between 1.8 and $2.1 \mathrm{~km}$.

\section{Experimental Overview}

Many investigators have contributed to the development of hydraulic fracturing equipment and test procedures that minimize the chances for test failures. As a result, when we are confident that anomalous data is not caused by a system problem, we can interpret the data in terms of the response of a fracture propagating in the $i n$ situ stress field. In the tests made in the DOSECC hole, mechanical pressure gauges mounted below the packer system were used to measure pressure in the isolated interval, in the inflatable packer elements, and in the hole below the packers. Temperaturecompensated quartz pressure gauges and a strain-gauge type of pressure transducer were mounted at the surface in a manifold used to control the fluid flow to the well head. Each type of gauge has advantages and disadvantages so a combination of gauges was needed to meet the requirements of the experiment. Two flow meters were used to measure flow into the well and two flow meters were used to measure flow back from the well. A schematic diagram of the hydrofrac system is shown in Figure 1 .

Automated air-driven valves were used in the manifold system for precise control of borehole pressurization. Extensive testing of the pumps, valves, and tubing prior to the down-hole tests essentially eliminated failure in these elements of the system. With these precautions, failure of the packer systems were the only serious technical problem. Based on the results from the measurements in the ARKOMA hole we anticipated that pressure as high as $140 \mathrm{MPa}$ at temperatures of about $200^{\circ} \mathrm{C}$ might be encountered during stress measurements in a hole $5 \mathrm{~km}$ deep at this site. There is no previous experience in the use of open-hole packer systems at these pressures and temperatures, and we worked with Tam International of Houston, Texas to develop new systems for this experiment. As a result of extensive engineering studies and field tests, we succeeded in developing a system that would contain pressures to $70 \mathrm{MPa}$ at temperatures to $100^{\circ} \mathrm{C}$ and we have built a prototype of a systern that will contain pressures to $140 \mathrm{MPa}$ at higher temperatures.

This paper is not subject to U.S. copyright. Published in 1988 by American Geophysical Union.

Paper number: 8L7396.
Test Sequence

The intervals suitable for hydraulic fracturing were selected primarily from borehole televiewer logs (see Barton and Moos, this issue; Shamir et al., this issue) and caliper logs. We attempted to locate sections of the borehole that were without pre-existıng fractures and were approximately the diameter of the drill bit. When these ideal eections could not be found or when the breakdown pressure from a previous frac attempt exceeded the strength of the packer system we selected zones with pre-existing fractures.

The packer system was lowered to the test interval on highpressure tubing. The pipe tally was checked with a four-conductor wireline system lowered through the tubing to the packer system. In most cases the wireline was the same system that was used to run the prefrac televiewer logs so we could tie the pipe tally depth to the depth scale of the televiewer records. The wireline system carried a plug, or dart, which seated in a port near the top of the packer system to close the fluid path to the interval between the two packers. With the dart in place, pressure applied to the tubing inflated the packers. The wireline was sealed at the surface with a rubber packoff system and pressure was applied to the tubing to attain the desired inflation pressure, between 7 and $35 \mathrm{MPa}$ depending on the anticipated breakdown pressure and least horizontal stress. The

HYDROFRAC SYSTEM COMPONENTS

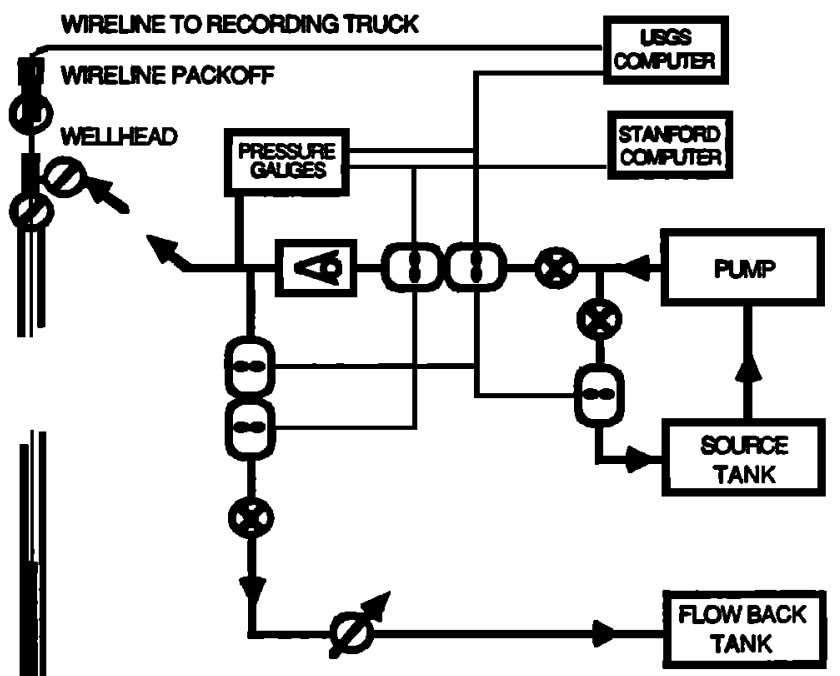

WRELINE RECORDERS

AND PRESSURE TRANSMTTER

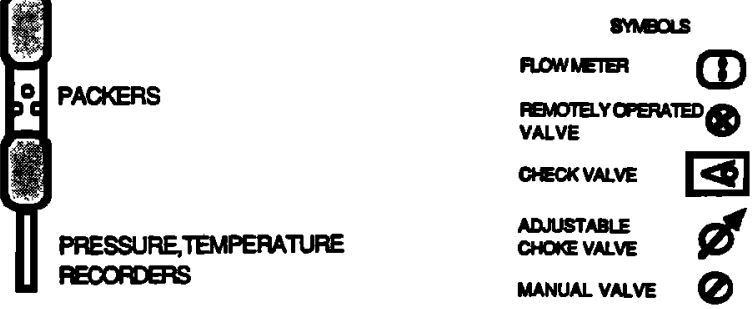

Figure 1. Schematic diagram of system components. 
pressure in the packer elements increased with the interval pressure so that the packers maintained a hydraulic seal against the borehole wall despite increasing pressure in the interval. We tried to select a packer-setting pressure that was greater that $1 / 3$ the anticipated breakdown pressure but less than the anticipated least horizontal stress.

\section{Results}

A variety of pressure-time records were obtained in these experiments depending on the conditions encountered. In this section we will illustrate the variety of data types with three examples.

Example A (Figure 2A). This measurement, which was made at a depth of 1277 meters in the ARKOMA hole, shows the downhole interval pressure and the rate of flow from the flow-in gauge. The test sequence consists of four pressurization cycles and a flow rate versus pressure test. We began the test at a pressure of $12.7 \mathrm{MPa}$ pumping at a rate of $19.4 \mathrm{~L} / \mathrm{Min}$. At a pressure of $19.4 \mathrm{MPa}$ we stopped the pump and closed the valve on the manifold to shutin the system. We held this pressure for 4 mimutes in the hope
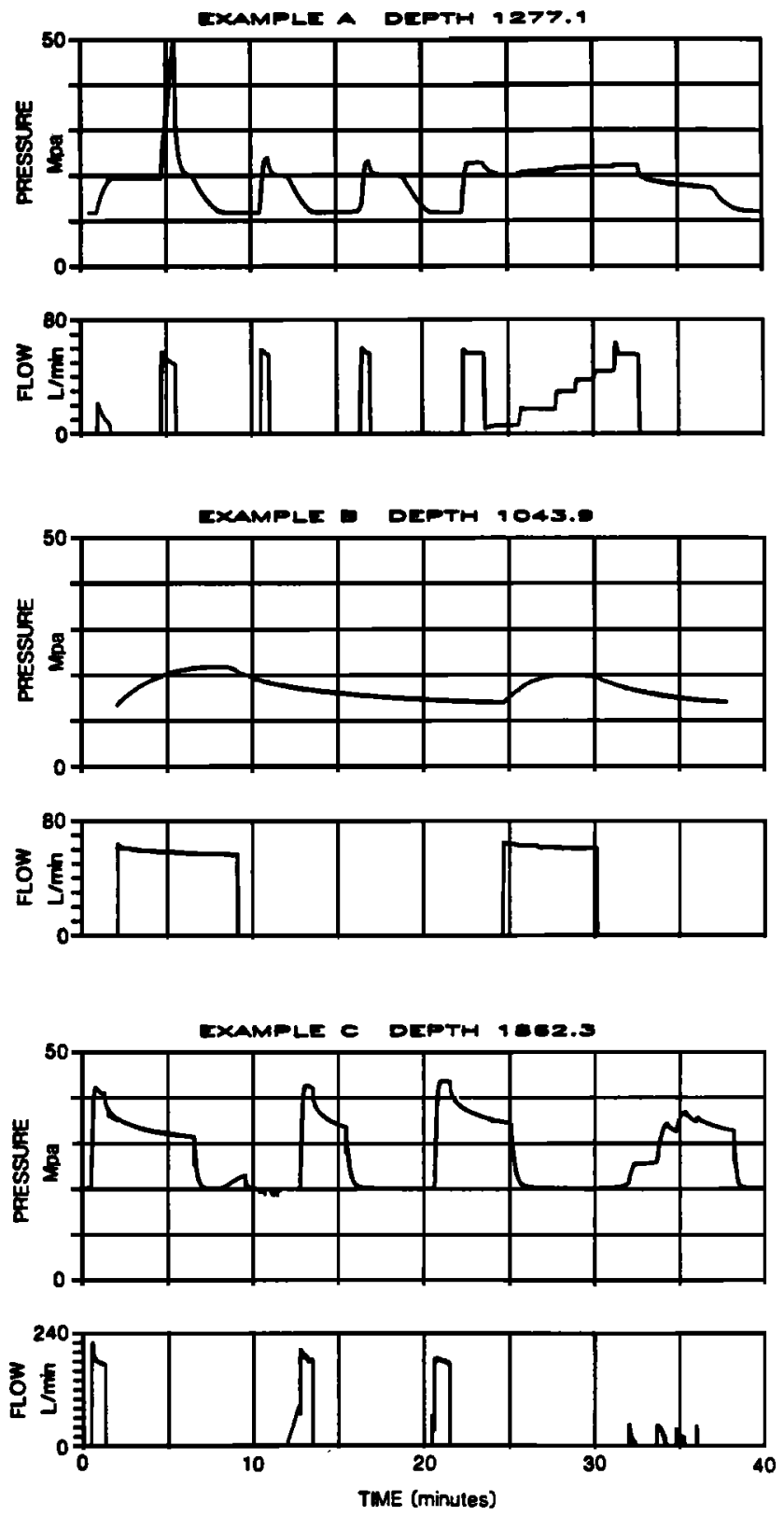

Figure 2. Plots of pressure and flow rate for three examples of hydrofracturing stress measurements. that some fluid penetration would lower the tensile strength of the rock as a previous test had failed because of extremely high breakdown pressures. The stable pressure observed during this pause demonstrates that there were no leaks in the system and that there was no measurable penetration of fluid into pre-existing fractures. We resumed pumping at a pressure of 19.4 MPa and the pressure rose linearly to breakdown $50.9 \mathrm{MPa}$. About 30 seconds after breakdown, the pump was stopped and the system shut-in. The instantaneous shut-in pressure (ISIP), indicating fracture closure, was picked at 20.7 MPa. The system was then opened to allow fluid to flow back out of the fracture and return the pressure to hydrostatic. This sequence was repeated three times to obtain the following results:

Cycle First Second Third Fourth

$\begin{array}{lllll}\begin{array}{l}\text { Starting pressure } \\ \text { in MPa }\end{array} & 12.6 & 12.7 & 12.7 & 12.7 \\ \begin{array}{l}P_{b} \text { (Frac opening } \\ \text { pressure) }\end{array} & 51.0 & 24.5 & 23.8 & 23.4 \\ \text { ISIP (shut in pressure) } & 25.7 & 22.9 & 21.9 & 22.5\end{array}$

At the end of the fourth cycle we conducted a flow-rate pressure test. We note the pressure observed at low flow rates, 21.7 MPa at $19.4 \mathrm{~L} / \mathrm{Min}$, is consistent with the ISIP values picked on the second, third and fourth cycles. In this case we take the frac opening pressure from the second cycle as the breakdown pressure with zero tensile strength $P_{b}(T=0)$. Subtracting this value from the breakdown on the first cycle we get $26.5 \mathrm{MPa}$ tensile strength which is high but not unusual for a mud-filled borehole (Zoback et al., 1977). With the instantaneous shut-in pressure (ISIP) values from the last three cycles and the flow-rate test close together we can average the four values to estimate the least horizontal stress, $S_{h \min }$. We calculate the vertical stress $S_{v}$ assuming a density of $2.3 \mathrm{gm} / \mathrm{cc}$ for the sedimentary rocks between the surface and 579 meters (an average depth to crystalline basement rock near the well) and a density of $2.6 \mathrm{gm} / \mathrm{cc}$ for the crystalline rocks below $\mathbf{5 7 9}$ meters. The pore pressure, $P_{0}$, at depth is estimated to be approximately hydrostatic (Coyle and Zoback, this issue). Using these values the greatest horizontal stress, $S_{H \max }$, is calculated from the relationship:

$$
P_{b}(T=0)=3 S_{h \min }=S_{H \max }-P_{o}
$$

after Haimson and Fairhurst (1970) but modified by Bredehoeft et al. (1976), and Hickman and Zoback (1983) for secondary pumping cycles where tensile strength is zero.

Example B (Figure 2B) is one of a series of tests made in the ARKOMA hole between 938 and 1180 meters. In this section of the hole the high breakdown pressures exceeded the strength of the packer system so we intentionally chose sections of the borehole with pre-existing fractures. In these tests the first pressurization cycle reflects the character of the pre-existing fractures but later cycles reflect the stress perpendicular to a new fracture that was propagated perpendicular to the least horizontal stress. In Figure 2B we show a test with only two cycles and pick the least horizontal stress from the inflection after shut-in on the second cycle.

Example C (Figure 2C) is an example of several of the tests that have pressure-time histories that are unusual and which makes interpretation somewhat complicated. In this example the breakdown pressure increases slightly on the second and third pressurization cycles. This unusual observation might occur if the interval pressure exceeded the packer element pressure and fluid leaked by the upper packer into the open hole without fracturing the rock. Two observations rule out this explanation. After the completion of the first cycle the system was opened and the pressure dropped to near hydrostatic. Then the system was closed again and the pressure rose as fluid was returned to the interval from a fracture. This observation shows that a fracture was formed and that the fracture contains fluid at high pressure. In this test we have gauges in the system to measure pressure in the packer elements and in the isolated interval. The pressure values measured before the start of each cycle and at the end of the test sequence were: 
We note that the element pressure dropped significantly (about $6 \mathrm{MPa}$ ) indicating a slow leak in the packer elements. However, the peak pressures measured in each cycle:

$\begin{array}{lllll}\text { Element } & 44.0 & 43.9 & 44.9 & 36.8 \\ \text { Interval } & 40.5 & 40.7 & 41.6 & 32.1\end{array}$

show that the element pressure always rose and remained sufficiently above the interval pressure to prevent flow past the packer elements. These data suggest that the packer inflation pressure has a small effect on breakdown pressure and the frac reopening pressures because the fracture reopening pressure increases slightly as the element pressure decreases. The fourth cycle is a flow-rate test. A clutch failure on the pump during this test prevented a standard flow test but we note that by the time of the fourth cycle the fracture has been propped open and begins to take fluid at low pressures. We picked points from this test as follows:

$\begin{array}{cccc}\text { Cycle } & \text { First } & \text { Second } & \text { Third } \\ \text { Frac opening } & 40.5 & 40.7 & 41.6 \\ \text { Shut In ISIP } & 35.6 & 36.2 & 38.0\end{array}$

From these observations we conclude that either a fracture formed at the time of the packer inflation or that the rock has low tensile strength. We take the average of the three frac opening pressures as a reasonable estimate of $P_{b}(T=0)$ and the average of the three shut-in pressures as an estimate of the least horizontal stress.

We hope that the discussion of these three examples will give the reader a sense of the quality and variety of the data and some of the problems in interpretation. We believe that the values we present here (Table 1, Figure 3) represent a reliable estimate of the least horizontal stress. The greatest horizontal stress is subject to larger error but we believe that these values are a good indication of real changes of the stress field even though their absolute magnitude is less certain. We estimate the uncertainty in $S_{h \text { min }}$ to be less than $1 \mathrm{MPa}$ and the uncertainty in $S_{H \max }$ to be less than $5 \mathrm{MPa}$.

There are three general observations about the data presented in Figure 3 and Table 1. First the computed values of the horizontal principal stresses calculated from the different types of tests are generally quite consistent. This is especially true of the $S_{h \text { min }}$ values at about one kilometer depth where data from new fractures and pre-existing fractures are in good agreement. Second, at all depths $S_{h m i n}$ is the least principal stress. At depths of about one kilometer
Cajon Pass In Situ Stress

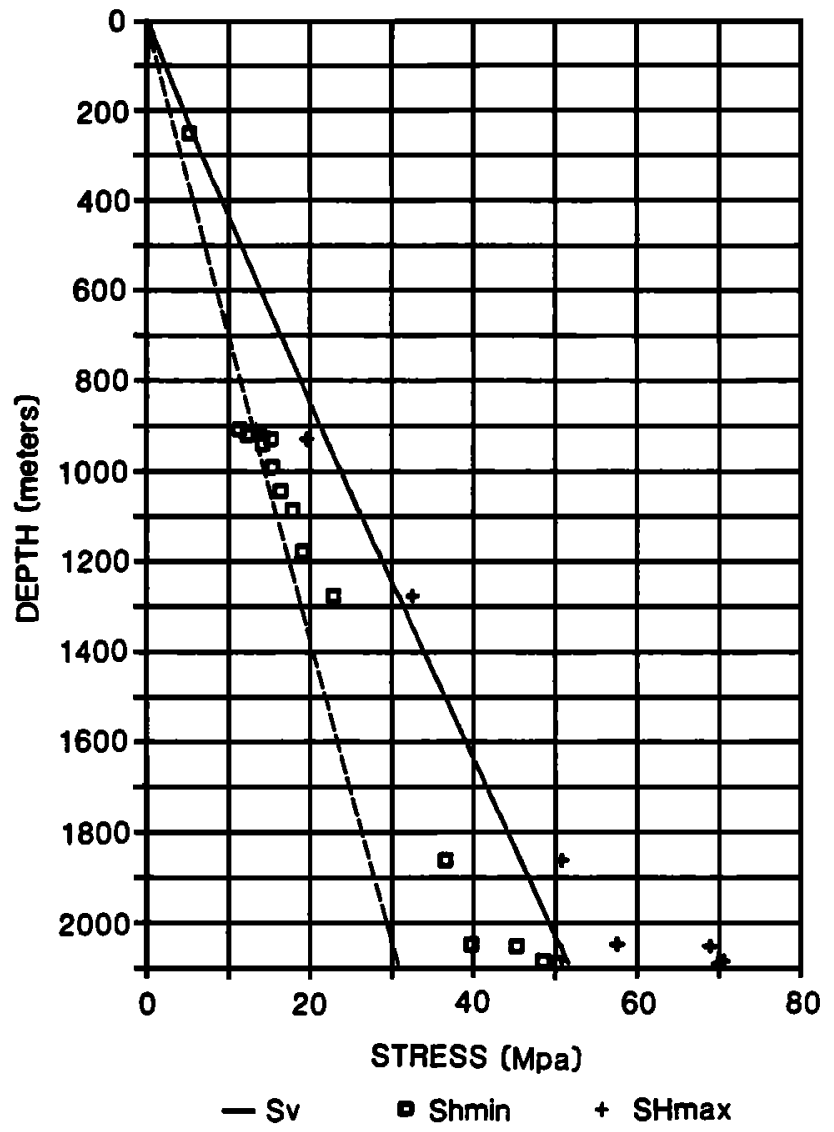

Figure 3. The three principal stresses plotted as a function of depth. The solid line is the estimated vertical stress from the density of the rock. The dashed line is the value of $S_{h m i n}$ at which normal faulting on pre-existing fractures occurs.

Table 1

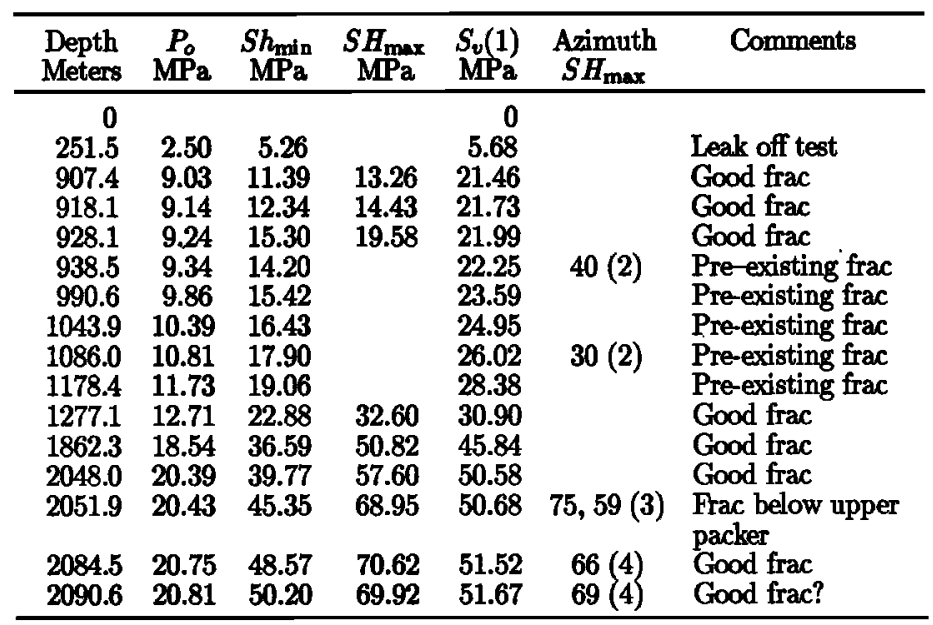

(1) Computed from weight of overlying rocks.

(2) Average direction of wellbore breakouts from four arm caliper log. Accuracy better than $20^{\circ}$ (G. Shamir, written communication).

(3) Average direction of wellbore breakouts from televiewer log. Accuracy better than $10^{\circ}$ (Shamir et al., this issue).

(4) Borehole televiewer image of hydrofracs; Accuracy better than $10^{\circ}$. 
$S_{H \max }$ is close to $S_{v}$ and at greater depths $S_{H \max }$ is greater than $S_{v}$. Third, there is a marked increase of both $S_{h \min }$ and $S_{H \max }$ between 2.0 and 2.1 kilometers.

\section{Discussion and Conclusion}

The northeasterly direction of the maximum compressive stress indicates an absence of right-lateral shear stress on planes parallel to the San Andreas Fault. There are two possible explanations for this observation. Fither the stress field observed to $2.1 \mathrm{~km}$ depth at the well gite is somehow decoupled from the stress field at the San Andreas Fault (a hypothesis that will be tested by deepening the well) or the San Andreas Fanlt is very weak compared to the adjacent crustal rocks. As a weak fault cannot sustain shear stress, the greatest horizontal stress will be either approximately parallel to or perpendicular to the strike of the fault (Zoback et al., 1987).

The measurements of stress magnitude indicate that the rocks are not responding elastically to uniform tectonic strain. It can be calculated that frictional sliding occurs when the greatest effective stress (the greatest principal stress minus the pore pressure) is about three times the least effective stress for a coefficient of friction of 0.6 and zero cohesive strength (Sibeon, 1974). In Figure 3 the dashed line shows the value of the least horizontal stress at which well-oriented normal fauls are in frictional equilibrium (see Zoback and Healy, 1983). At depths between 900 and 1000 meters the least horizontal stress reaches the normal faulting line and is consistent with small-scale normal faulting in the general area of the hole (Weldon and Springer, this issue). Between 1000 meters and 2000 meters the stress difference, $S_{v}-S_{h \min }$, is relatively constant and then $S_{h \min }$ increases rapidly until it is nearly equal to $S_{v}$ at $2.09 \mathrm{~km}$. This sudden change in the character of the stress field at two kilometers requires a local dislocation such as an active fault that intersects the borehole. Regardless of its origin, the abrupt stress change near the bottom of the hole indicates that it is not possible to extrapolate the measurements reported here to greater depth. Deeper measurements are clearly necessary to estimate the level of shear stress driving the San Andreas Fault.

Acknowledgements. Many people made very important contributions to this experiment. Personnel from the U.S. Geological Survey, Stanford University, and DOSECC made major contributions. Personnel from Haliburton, Tam International, and Schlumberger made contributions far beyond the requirements of their contractural obligations. We especially acknowledge the assistance of Tom Moses and Dennis Styles of the USGS, Bob Johnson of DOSECC, and Ted Benscoter of Haliburton for their contribution in field operations. We thank Mark Ader and Brennan 0'Neill for their assistance in the preparation of this paper.
References

Barton, C.A. and D. Moos, Natural fractures in the Cajon Pass scientific drillhole and their effect on rock properties, Geophys. Res. Lett., this issue, 1988.

Bredehoeft, J.D. et al., Hydraulic fracturing to determine the regional stress field, Piceance Basin, Colorado, Geol. Soc. Amer. Bull., 87, 250-258, 1976.

Coyle, B. and M.D. Zoback, In situ permeability and fluid pressure measurements at approx. $2 \mathrm{~km}$ depth in the Cajon Pass research well, Geophys. Res. Lett., this issue, 1988.

Haimson, B.C. and C. Fairhurst, In situ stress determination at great depth by means of hydraulic fracturing, in Proc. 11th Symp. on Rock Mech., AIME, New York, 559-589, 1970.

Hickman, S.H. and M.D. Zoback, The interpretation of hydraulic fracturing data for in situ stress determination, in Hydraulic Fracturing Stress Measurements, eds. M.D. Zoback and B.C. Haimson, National Academy Press, Wash., D.C., 1983.

Shamir, G., et al., In situ stress orientation near the San Andreas fault: Preliminary results to $2.1 \mathrm{~km}$ depth from the Cajon Pass scientific drillhole, Geophys. Res. Lett., this issue, 1988.

Sibson, R.H., Frictional constraints on thrust, wrench and normal faults, Nature, 249, 542-544, 1974.

Weldon, R.J. and J.E. Springer, Active faulting near the Cajon Pass well, Southern California: Implications for the stress orientation near the San Andreas fault, Geophys. Res. Lett., this issue, 1988.

Zoback, M.D., R. Rummel, R. Jung and C.B. Raleigh, Laboratory hydraulic fracturing experiments in intact and prefractured rock, Int. Jour. Rock Mech. Min. Sci., 14(2), 49-58, 1977.

Zoback, M.D. and J.H. Healy, Friction, faulting and in situ stress, Annales Geophysicae, 2, 689-698, 1983.

Zoback, M.D., et al., New Evidence on the state of stress of the San Andreas fault, Science, 238, 1105-1111, 1987.

Zoback, M.D., et al., The Cajon Pass scientific drilling experiment: Overview of Phase I, Geophys. Res. Lett., this issue, 1988.

J. Healy (U.S. Geological Survey, Menlo Park, CA 94025), M.D. Zoback (Dept. of Geophysics, Stanford University, Stanford, CA 94305).
(Received: May 27, 1988

revised: July 23,1988

accepted: July 27, 1988) 